\title{
Alkaline peroxide pretreatment of corn stover: effects of biomass, peroxide, and enzyme loading and composition on yields of glucose and xylose
}

\author{
Goutami Banerjee', Suzana Car ${ }^{1}$, John S Scott-Craig ${ }^{1}$, David B Hodge ${ }^{1,2}$ and Jonathan D Walton ${ }^{1,3^{*}}$
}

\begin{abstract}
Background: Pretreatment is a critical step in the conversion of lignocellulose to fermentable sugars. Although many pretreatment processes are currently under investigation, none of them are entirely satisfactory in regard to effectiveness, cost, or environmental impact. The use of hydrogen peroxide at pH 11.5 (alkaline hydrogen peroxide (AHP)) was shown by Gould and coworkers to be an effective pretreatment of grass stovers and other plant materials in the context of animal nutrition and ethanol production. Our earlier experiments indicated that AHP performed well when compared against two other alkaline pretreatments. Here, we explored several key parameters to test the potential of AHP for further improvement relevant to lignocellulosic ethanol production.

Results: The effects of biomass loading, hydrogen peroxide loading, residence time, and pH control were tested in combination with subsequent digestion with a commercial enzyme preparation, optimized mixtures of four commercial enzymes, or optimized synthetic mixtures of pure enzymes. AHP pretreatment was performed at room temperature $\left(23^{\circ} \mathrm{C}\right)$ and atmospheric pressure, and after AHP pretreatment the biomass was neutralized with $\mathrm{HCl}$ but not washed before enzyme digestion. Standard enzyme digestion conditions were $0.2 \%$ glucan loading, $15 \mathrm{mg}$ protein/g glucan, and $48 \mathrm{~h}$ digestion at $50^{\circ} \mathrm{C}$. Higher pretreatment biomass loadings (10\% to 20\%) gave higher monomeric glucose (Glc) and xylose (Xyl) yields than the $2 \%$ loading used in earlier studies. $\mathrm{An}_{2} \mathrm{H}_{2}$ loading of $0.25 \mathrm{~g} / \mathrm{g}$ biomass was almost as effective as $0.5 \mathrm{~g} / \mathrm{g}$, but $0.125 \mathrm{~g} / \mathrm{g}$ was significantly less effective. Optimized mixtures of four commercial enzymes substantially increased post-AHP-pretreatment enzymatic hydrolysis yields at all $\mathrm{H}_{2} \mathrm{O}_{2}$ concentrations compared to any single commercial enzyme. At a pretreatment biomass loading of $10 \%$ and an $\mathrm{H}_{2} \mathrm{O}_{2}$ loading of $0.5 \mathrm{~g} / \mathrm{g}$ biomass, an optimized commercial mixture at total protein loadings of 8 or 15 $\mathrm{mg} / \mathrm{g}$ glucan gave monomeric Glc yields of $83 \%$ or $95 \%$, respectively. Yields of Glc and Xyl after pretreatment at a low hydrogen peroxide loading $\left(0.125 \mathrm{~g} \mathrm{H}_{2} \mathrm{O}_{2} / \mathrm{g}\right.$ biomass $)$ could be improved by extending the pretreatment residence time to $48 \mathrm{~h}$ and readjusting the $\mathrm{pH}$ to 11.5 every $6 \mathrm{~h}$ during the pretreatment. A Glc yield of $77 \%$ was obtained using a pretreatment of $15 \%$ biomass loading, $0.125 \mathrm{~g} \mathrm{H}_{2} \mathrm{O}_{2} / \mathrm{g}$ biomass, and $48 \mathrm{~h}$ with $\mathrm{pH}$ adjustment, followed by digestion with an optimized commercial enzyme mixture at an enzyme loading of $15 \mathrm{mg}$ protein $/ \mathrm{g}$ glucan.
\end{abstract}

Conclusions: Alkaline peroxide is an effective pretreatment for corn stover. Particular advantages are the use of reagents with low environmental impact and avoidance of special reaction chambers. Reasonable yields of monomeric Glc can be obtained at an $\mathrm{H}_{2} \mathrm{O}_{2}$ concentration one-quarter of that used in previous AHP research. Additional improvements in the AHP process, such as peroxide stabilization, peroxide recycling, and improved $\mathrm{pH}$ control, could lead to further improvements in AHP pretreatment.

\footnotetext{
* Correspondence: walton@msu.edu

'Department of Energy, Great Lakes Bioenergy Research Center, Michigan

State University, East Lansing, MI, USA

Full list of author information is available at the end of the article
} 


\section{Background}

The biochemical route for conversion of lignocellulose to biofuels is based on the fermentation of the sugars contained in plant cell wall polysaccharides. Generating fermentable sugars from lignocellulose can be achieved by a pretreatment coupled to an enzymatic depolymerization. Pretreatment chemistries can involve chemical modification, depolymerization, and/or solvation, resulting in physical redistribution of lignin and hemicelluloses and potentially altering cellulose crystallinity [1-4]. Many pilot and commercialization pretreatment processes are utilizing acidic pretreatments such as hot water, dilute acid $\left(\mathrm{H}_{2} \mathrm{SO}_{4}\right.$ or $\left.\mathrm{SO}_{2}\right)$, and steam explosion. These are typically performed at temperatures in excess of $160^{\circ} \mathrm{C}$ and result in lignin melting and redistribution, hemicellulose solubilization and depolymerization, release of acetate from hemicelluloses, and the formation of furans from the acid-catalyzed dehydration of sugars. Other pretreatment alternatives include concentrated acid processes [5-7] and ionic liquids [8], which are based on decrystallizing cellulose; pretreatments based on ammonia $[9,10]$; a range of organosolv processes [11]; and delignifying alkaline and oxidative pretreatments such as wet oxidation [12-14] and alkaline hydrogen peroxide [15].

An ideal pretreatment would be effective (enable high sugar yields in a short time at low enzyme loading), simple (avoidance of multiple biomass handling steps), inexpensive (low capital equipment, energy, and chemical input requirements), and compatible with high biomass loadings. An ideal pretreatment would also minimize water consumption and not release or generate inhibitors of downstream operations (that is, enzyme digestion and fermentation). Current pretreatment methods are less than ideal in one or more of these characteristics. For example, although organic solvent/phosphoric acid mixtures and ionic liquids are very effective at rendering biomass amenable to enzymatic hydrolysis, they require high concentrations of expensive reagents [6-8]. Ammonia fiber expansion (AFEX), ammonia recycled percolation (ARP), $\mathrm{SO}_{2}$, and dilute acid operate at high pressure and/or high temperature and thus require capital-intensive and corrosion-resistant reactors. Acid pretreatment generates fermentation inhibitors, and lime requires long (4 week) residence times $[3,13]$.

Pretreatment using hydrogen peroxide at $\mathrm{pH} 11.5$, herein referred to as alkaline hydrogen peroxide (AHP), has been shown by Gould and colleagues to be effective for subsequent ruminant and in vitro enzyme digestibility [15-18]. AHP has been applied to corn stover $[19,20]$, barley straw [21], wheat straw [22,23], bamboo [24], rice straw [25], softwood [26], sugarcane bagasse [27], Miscanthus [28] and other herbaceous and woody plants [29]. Saha and Cotta [21,22] reported that AHP compared favorably against dilute acid or lime pretreatment of barley straw for subsequent enzymatic sugar release, and that post-pretreatment washing was not required. AHP has been successfully operated in a continuous flow operation at high biomass loading (approximately 40\% solids) and low $\mathrm{H}_{2} \mathrm{O}_{2}$ loading [30]. Nevertheless, AHP is relatively unstudied compared to other thermochemical pretreatments and has generally not been included in comparative studies and reviews [1-4].

In earlier experiments, we found that AHP compared favorably against dilute base $(0.25 \% \mathrm{NaOH})$ or AFEX as a pretreatment for corn stover, Miscanthus, and switchgrass [20]. AHP pretreatment of corn stover yielded 18\% more monomeric glucose (Glc) than AFEX (69\% of total available Glc vs $52 \%$ ) when the pretreated material was enzymatically hydrolyzed with a 16-component synthetic mixture at an enzyme loading of $15 \mathrm{mg}$ protein/g glucan. Monomeric xylose (Xyl) yields were also higher from corn stover pretreated by AHP compared to AFEX (55\% vs $41 \%$ of available Xyl) [20].

The AHP conditions used earlier [20] were essentially those developed by Gould [15,29], namely, a biomass loading of $2 \%$, an $\mathrm{H}_{2} \mathrm{O}_{2}$ loading of $0.5 \mathrm{~g} / \mathrm{g}$ biomass, and $24 \mathrm{~h}$ residence time at $23^{\circ} \mathrm{C}$. In order to determine if the AHP process relevant to biomass conversion could be improved, we examined the effects of changing several AHP parameters on Glc and Xyl yields. We tested AHP-stover digestibility by single commercial enzyme cocktails, optimized mixtures of commercial cocktails, and synthetic mixtures of pure enzymes.

\section{Methods \\ Biological materials}

Corn stover (Zea mays L. Pioneer hybrid 36H56) was ground to pass a $5 \mathrm{~mm}$ screen and stored at room temperature. This material is called 'GLBRC stover' $[20,31,32]$. Before use, it was further ground in a Wiley mill to pass a screen size of $0.5 \mathrm{~mm}$. No portion of the original material was discarded during any step of grinding. The final material contains $34.4 \%(\mathrm{w} / \mathrm{w})$ Glc and $22.4 \%(w / w)$ Xyl. AFEX-pretreated material was ground in a Wiley mill to pass a screen size of $0.25 \mathrm{~mm}$ after pretreatment. For AFEX-pretreated corn stover, whether the grinding is performed before or after the AFEX treatment does not affect subsequent enzymatic digestibility [33].

Particle size has a large effect on enzymatic digestibility. Specifically, AFEX-pretreated corn stover ground to $<0.1 \mathrm{~mm}$ was shown in a side-by-side comparison to give absolute monomeric Glc yields that are 20 to $30 \%$ higher than AFEX-stover ground to pass a $0.5 \mathrm{~mm}$ 
screen size [32]. The material used in the current paper was ground to pass a screen size of $0.25-0.5 \mathrm{~mm}$ [32].

Commercial enzymes and purified enzymes were from the same lots described earlier [20,31,32].

\section{Pretreatments}

For AHP, a solution of $\mathrm{H}_{2} \mathrm{O}_{2}$ (diluted from a commercial 30\% stock, J.T. Baker ACS Reagent Grade) was titrated to $\mathrm{pH} 11.5( \pm 0.2)$ with $5 \mathrm{M} \mathrm{NaOH}$ and mixed with the biomass. When comparing different biomass loadings, a fixed amount of biomass $(1 \mathrm{~g})$ was added to a fixed amount of $\mathrm{H}_{2} \mathrm{O}_{2}$ plus $\mathrm{NaOH}$ and a variable amount of water to give the desired final biomass loading. The experimental details of quantities and loadings of biomass, $\mathrm{H}_{2} \mathrm{O}_{2}, \mathrm{NaOH}$, and water are given in Additional file 1, Table S1. Pretreatment biomass loadings are given as nominal $\% \mathrm{w} / \mathrm{v}$, for example, $10 \%=1 \mathrm{~g}$ biomass plus $10 \mathrm{ml}$ pretreatment solution. All pretreatments were performed at $23^{\circ} \mathrm{C}$ in $125 \mathrm{ml}$ flasks with shaking at $90 \mathrm{rpm}$ for $24 \mathrm{~h}$ or $48 \mathrm{~h}$. After AHP pretreatment, the biomass suspensions were neutralized to approximately $\mathrm{pH} 7$ with concentrated $\mathrm{HCl}$, treated with catalase to destroy residual $\mathrm{H}_{2} \mathrm{O}_{2}$, heated at $90^{\circ} \mathrm{C}$ for 15 $\mathrm{min}$ to inactivate the catalase, and lyophilized to dryness [20].

At the lowest $\mathrm{H}_{2} \mathrm{O}_{2}$ loading used in our experiments (0.125 g/g biomass), the $\mathrm{pH}$ tended to drift downward during the pretreatment incubation. In ' $\mathrm{pH}$ adjustment' experiments, the $\mathrm{pH}$ was maintained at 11.5 by addition of $5 \mathrm{M} \mathrm{NaOH}$ every $6 \mathrm{~h}$ (see Results). The amounts of $\mathrm{NaOH}$ added in these experiments are shown in Additional file 1, Table S2.

For AFEX pretreatment, GLBRC stover $(5 \mathrm{~mm}$ particle size) was treated at an ammonia to biomass ratio of 2:1, a moisture content of $200 \%$, a temperature of $150^{\circ} \mathrm{C}$, and a residence time of $30 \mathrm{~min}$. These AFEX conditions were more severe than those used previously $[20,31,32]$.

\section{Enzymatic hydrolysis}

The enzyme optimization platform GENPLAT was used to dispense stover slurries and enzymes. GENPLAT incorporates automated dispensing of stover slurry and enzymes into 96-well plates, statistical experimental design, and enzyme-mediated colorimetric determination of monomeric Glc and Xyl [20,31,32]. The final biomass concentration was $0.2 \%$ glucan (as monomeric Glc) suspended in $50 \mathrm{mM}$ sodium citrate, $\mathrm{pH}$ 4.6. The mass of the salt introduced by the $\mathrm{NaOH}$ used for pretreatment and the $\mathrm{HCl}$ used for $\mathrm{pH}$ neutralization was taken into account when calculating glucan concentrations for the enzyme digestions (Additional file 1, Table S3) [20].

Optimization experiments with four-component commercial enzyme cocktail mixtures used an augmented quadratic experimental design and a fixed enzyme protein loading of $15 \mathrm{mg} / \mathrm{g}$ glucan. The lower limit of each of the commercial enzymes was set to $0 \%$. The 11 -component mixture experiments with purified enzymes also used a total protein loading of $15 \mathrm{mg} / \mathrm{g}$ glucan and an augmented quadratic design, which entailed 78 individual reactions. The lower limit for the 'core' enzymes (cellobiohydrolase 1 (CBH1), $\mathrm{CBH} 2$, endo- $\beta 1$,4-glucanase 1 (EG1), $\beta$-glucosidase (BG), $\beta$-xylosidase (BX), and endo- $\beta 1,4-x y l a n a s e ~ 3$ (EX3)) were set to $4 \%$, whereas the lower limit of all of the other 'accessory' proteins was set to $0 \%$ [20]. Each enzyme mixture was replicated once, sampled twice, and monomeric Glc and Xyl measured twice, for a total $n=8$. For enzyme dose response experiments, the stover and enzyme mixtures (of a single proportional composition) were dispensed using the GENPLAT liquid handling robot, as stated in the figure legends.

\section{Effect of freeze drying on subsequent enzymatic hydrolysis}

After AHP pretreatment and neutralization, biomass samples were typically lyophilized. The main reason for this was a concern about the stability of wet biomass during storage prior to the enzyme hydrolysis step. However, air drying biomass has been shown to adversely affect subsequent enzymatic digestibility [34], and therefore the effect of lyophilization on digestibility was tested. Corn stover $(10 \mathrm{~g})$ was placed in each of two $500 \mathrm{ml}$ glass bottles at a final biomass loading of $10 \%$ and subjected to AHP pretreatment for $24 \mathrm{~h}$ at an $\mathrm{H}_{2} \mathrm{O}_{2}$ loading of $0.5 \mathrm{~g} / \mathrm{g}$ biomass. One sample was then lyophilized whereas the other sample was subjected directly to enzymatic hydrolysis. The enzymatic hydrolysis conditions for both samples were $0.2 \%$ glucan loading, $15 \mathrm{mg}$ enzyme/g glucan, $\mathrm{pH} 4.6,48 \mathrm{~h}$, and $50^{\circ} \mathrm{C}$. The enzyme mixture comprised 64\% Accellerase 1000, 9\% Multifect Xylanase, and 27\% Multifect Pectinase, which proportions were derived from small-scale experiments with the same pretreatment conditions (see Results). Digestibilities of the two samples were within $3 \%$ of each other ( $95 \pm 2.2 \%$ for lyophilized vs $92 \pm 2.0 \%$ for nonlyophilized; $\mathrm{n}=3, \pm 1 \mathrm{SD}$ ). We conclude that drying the pretreated biomass by lyophilization does not reduce subsequent sensitivity to enzymatic hydrolysis and is therefore an acceptable procedure.

\section{Results}

Influence of biomass, $\mathrm{H}_{2} \mathrm{O}_{2}$, and enzyme loadings

Initial AHP conditions were $2 \%$ biomass loading, $0.5 \mathrm{~g}$ $\mathrm{H}_{2} \mathrm{O}_{2} / \mathrm{g}$ biomass, $\mathrm{pH} 11.5,24 \mathrm{~h}$ residence time, and $21^{\circ}$ $\mathrm{C}$ to $24^{\circ} \mathrm{C}$ (that is, room temperature) $[15,16,20,29]$. In our experiments, corn stover pretreated in this way yielded $68.6 \%$ of total available monomeric Glc after 
digestion for $48 \mathrm{~h}$ with Accellerase 1000 at an enzyme loading of $15 \mathrm{mg} / \mathrm{g}$ glucan [20].

To determine if AHP could be further improved, we initially tested the influence of biomass loading. In this and all other experiments, the biomass was not washed or otherwise fractionated after pretreatment. That is, the entire material was freeze dried after AHP treatment and used as the substrate for enzymatic hydrolysis. The calculations of glucan content take into consideration the masses of the added salt (as $\mathrm{NaOH}$ plus $\mathrm{HCl}$ ).

On increasing the biomass loading from $2 \%$ to $10 \%$ (see Additional file 1, Table S1 for the details of the reaction recipes), monomeric Glc release increased from $70 \%$ to $82 \%$ after $48 \mathrm{~h}$ digestion with Accellerase 1000 (Figure 1). That is, increasing the biomass loading increased the effectiveness of AHP. These experiments were performed by reducing the water content of the reaction mixtures while maintaining the $\mathrm{H}_{2} \mathrm{O}_{2}$ loading per $\mathrm{g}$ biomass constant, and therefore the molar concentrations of $\mathrm{H}_{2} \mathrm{O}_{2}$ and $\mathrm{NaOH}$ in the liquid phase increased with increasing biomass loading. The use of higher biomass loadings with these conditions is thus advantageous in terms of water consumption and digestibility but does not consume less $\mathrm{H}_{2} \mathrm{O}_{2}$ or $\mathrm{NaOH}$ per unit of treated biomass.

Enzyme digestibility of biomass pretreated at different loadings was studied in more detail as a function of enzyme loading and digestion time. At $6 \mathrm{~h}$, Glc yields were similar for all biomass loadings and were close to linear as a function of enzyme loading up to $45 \mathrm{mg} / \mathrm{g}$ glucan (Figure 2). By $48 \mathrm{~h}$, Glc yields plateaued above an Accellerase 1000 loading of approximately $15 \mathrm{mg} / \mathrm{g}$ glucan (the lowest enzyme loading tested in this experiment), resulting in a Glc yield of approximately $82 \%$ (Figure 2).

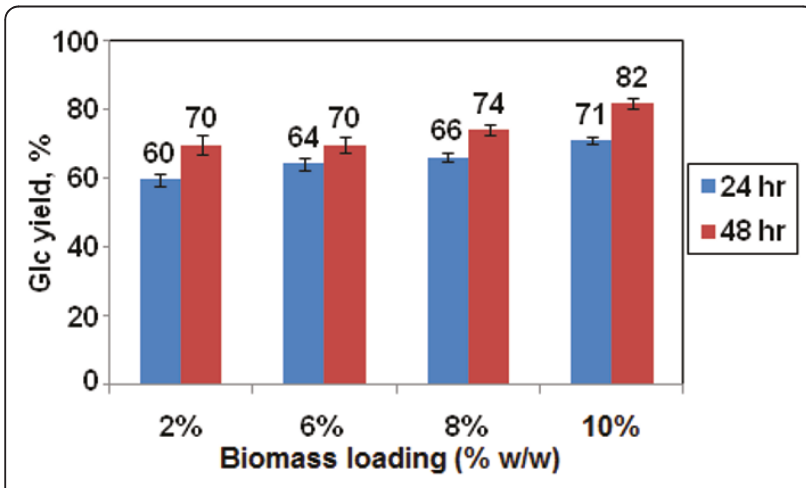

Figure 1 Effect of pretreatment biomass loading on monomeric glucose (GIc) yield. After pretreatment for $24 \mathrm{~h}$ at the indicated biomass loadings at $0.5 \mathrm{~g} \mathrm{H}_{2} \mathrm{O}_{2} / \mathrm{g}$ biomass, the biomass was neutralized, diluted to $0.2 \%$ glucan, and digested with Accellerase 1000 (15 mg/g glucan) for 24 or $48 \mathrm{~h}$. Error bars represent \pm 1 SD $(n=8)$.
The effect of lower $\mathrm{H}_{2} \mathrm{O}_{2}$ loadings was then tested. An $\mathrm{H}_{2} \mathrm{O}_{2}$ loading of $0.25 \mathrm{~g} / \mathrm{g}$ biomass was almost as effective for Glc release as $0.5 \mathrm{~g} / \mathrm{g}$ ( $74 \%$ Glc vs $82 \%)$. However, $0.125 \mathrm{~g} / \mathrm{g}$ was much less effective (that is, $46 \% \mathrm{Glc}$ release) (Figure 3a). A similar trend of decreasing yield with decreasing $\mathrm{H}_{2} \mathrm{O}_{2}$ loading was seen for Xyl (Figure $3 b)$.

The lowest enzyme loading tested in these experiments was $15 \mathrm{mg} / \mathrm{g}$ glucan, which for the higher $\mathrm{H}_{2} \mathrm{O}_{2}$ loadings at $48 \mathrm{~h}$ was already at or near a plateau of maximum Glc release (Figures $2 \mathrm{~d}$ and $3 \mathrm{a}$ ). Therefore, lower enzyme loadings were examined. Glc yields declined at enzyme loadings below approximately 15 $\mathrm{mg} / \mathrm{g}$ glucan (from $83 \%$ Glc at $15 \mathrm{mg} / \mathrm{g}$ glucan to $74 \%$ at $8 \mathrm{mg} / \mathrm{g}$ ) (Figure 3c). This indicates that the lowest enzyme loading that gave maximum Glc yield was, in fact, approximately $15 \mathrm{mg} / \mathrm{g}$ glucan (Figures $2 \mathrm{~d}$ and $3 \mathrm{a}$ ).

\section{Optimization of commercial enzyme cocktail mixtures for different $\mathrm{H}_{2} \mathrm{O}_{2}$ loadings}

A critical feature of an effective pretreatment is high sugar yields at low enzyme loadings [4]. Accellerase 1000 is rich in cellulases but relatively deficient in xylanases $[20,35]$. To test the effectiveness of AHP in combination with a superior enzyme cocktail, a mixture of four commercial enzymes (Accellerase 1000, Multifect Xylanase, Multifect Pectinase, and Novozyme 188) was optimized using GENPLAT. The total enzyme loading was fixed at $15 \mathrm{mg} / \mathrm{g}$ glucan. Proportions of the four enzymes were independently optimized for each of three $\mathrm{H}_{2} \mathrm{O}_{2}$ concentrations $(0.5,0.25$, and $0.125 \mathrm{~g} / \mathrm{g}$ biomass). An optimized mixture of the four enzymes was superior to Accellerase 1000 alone at all $\mathrm{H}_{2} \mathrm{O}_{2}$ loadings. At 0.125 $\mathrm{g} \mathrm{H}_{2} \mathrm{O}_{2}$ /g biomass, monomeric Glc yields improved from $46 \%$ to $55 \%$ compared to Accellerase 1000 alone, and at $0.25 \mathrm{~g} / \mathrm{g}$ biomass, Glc yields improved from $74 \%$ to $83 \%$ (Figure $3 \mathrm{a}$, Table 1). At $0.5 \mathrm{~g} \mathrm{H}_{2} \mathrm{O}_{2} / \mathrm{g}$ biomass, Glc yields increased from $82 \%$ to $95 \%$. Monomeric Xyl yields, optimized only with $0.5 \mathrm{~g} \mathrm{H}_{2} \mathrm{O}_{2} / \mathrm{g}$, increased from 34\% with Accellerase 1000 alone to $75 \%$ with an optimized mixture of the four enzymes (compare Figure 3b and Table 1).

The corresponding ternary diagrams for optimized mixtures of the four commercial enzymes on biomass treated with $0.5 \mathrm{~g} \mathrm{H}_{2} \mathrm{O}_{2} / \mathrm{g}$ are shown in Figure 4. Compared to the Glc ternary diagrams, the Xyl diagrams (Figure 4c,d) evidenced a relatively flat topology, that is, multiple solutions gave optimal Xyl release within a few percent of each other. This is reasonable considering that all four of the commercial enzymes contain xylanase activity, and therefore Xyl yield is not as strongly dependent as Glc yield on their relative proportions.

A trend in relative proportions of the four enzymes when going from low to high $\mathrm{H}_{2} \mathrm{O}_{2}$ loadings was the 

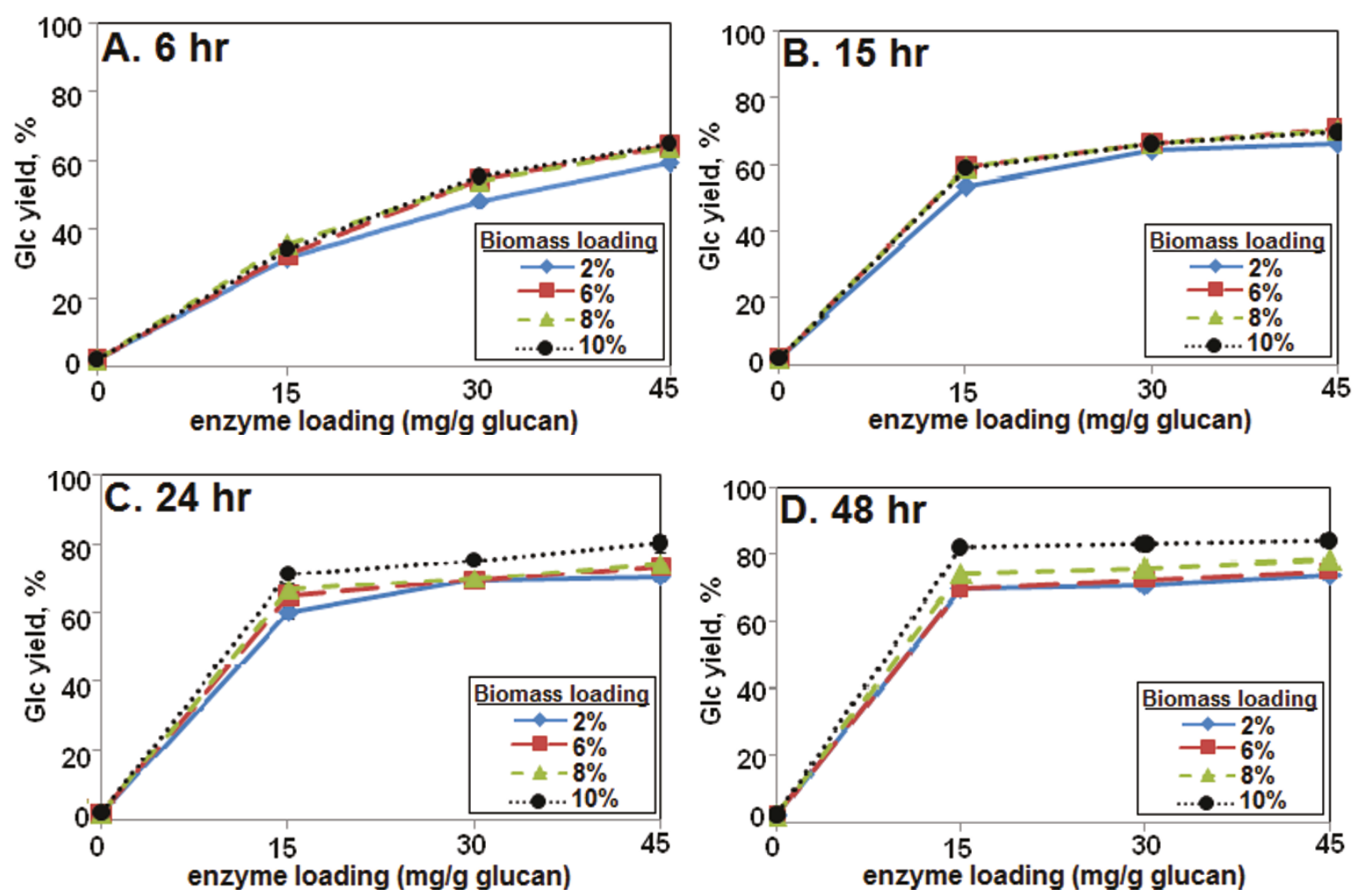

Figure 2 Effect of pretreatment biomass loading, enzyme loading, and hydrolysis time on monomeric glucose (GIc) yields. Biomass loadings ranged from $2 \%$ to 10\%, enzyme loadings from 0 to $45 \mathrm{mg} / \mathrm{g}$ glucan, and digestion times from 6 to $48 \mathrm{~h}$. Glc yield values indicate yield as a percentage of total measured monomeric Glc content of the biomass. The enzyme was Accellerase 1000.

decreasing importance of Multifect Xylanase and the increasing importance of Multifect Pectinase (Table 1, Figure 5). A possible explanation for this is that more severe pretreatments (that is, at higher $\mathrm{H}_{2} \mathrm{O}_{2}$ loading) are more effective at dissociating xylan from cellulose, and thus less xylanase is required to facilitate access of the cellulases to the cellulose $[31,35]$. This hypothesis assumes that it is actually the endo- $\beta 1,4$-xylanase activity in Multifect Xylanase that contributes to Glc release. Why Multifect Pectinase showed the opposite trend of becoming more important at higher $\mathrm{H}_{2} \mathrm{O}_{2}$ loading is less clear. This enzyme preparation contains more than 130 proteins and is particularly rich in enzymes active on hemicelluloses and pectins, many of which could potentially contribute to Glc yield (JS Scott-Craig and JD Walton, unpublished results).

A mixture of the four commercial enzymes was also optimized for AFEX-pretreated corn stover (Table 1, Figure 4). With the optimized mixture, the yield of Glc was somewhat higher from AFEX-corn stover than from stover pretreated with an $\mathrm{H}_{2} \mathrm{O}_{2}$ loading of $0.125 \mathrm{~g} / \mathrm{g}$ (61.5 vs 55.0\%). However, AFEX was much less effective than either 0.25 or $0.5 \mathrm{~g} \mathrm{H}_{2} \mathrm{O}_{2} / \mathrm{g}$ biomass $(61.5 \%$ vs $83.0 \%$ or $95.0 \%$, respectively) (Table 1 ).
There were striking differences between the optimal proportions of the four commercial enzyme preparations for AHP-stover compared to AFEX-stover. The optimal proportion of Accellerase 1000 was approximately $60 \%$ to $65 \%$ for both, but a higher proportion of Multifect Xylanase was needed for release of Glc from AFEXstover than from stover subjected to any of the AHP conditions (Table 1, Figure 4). That is, for AFEX-stover, the optimal proportion of Multifect Xylanase was 34\%, whereas the optimal proportion for AHP-stover ranged from $9 \%$ to $25 \%$ (Table 1). In place of Multifect Xylanase, Multifect Pectinase was relatively more important for Glc release from AHP-stover at all $\mathrm{H}_{2} \mathrm{O}_{2}$ loadings (optima ranging from 16\% to 25\%) but was not required at all for Glc release from AFEX-stover (that is, an optimum of $0 \%$ ) (Table 1, Figure 4). At this point, it is difficult to speculate about the reasons for these differences between AFEX and AHP, mostly because of the poorly defined complexity of these commercial enzyme preparations.

The effect of varying the enzyme loading on monomeric Glc yields was examined with the four-enzyme cocktails optimized for the conditions shown in Table 1 (that is, $15 \mathrm{mg}$ enzyme/g glucan and $48 \mathrm{~h}$ hydrolysis). 

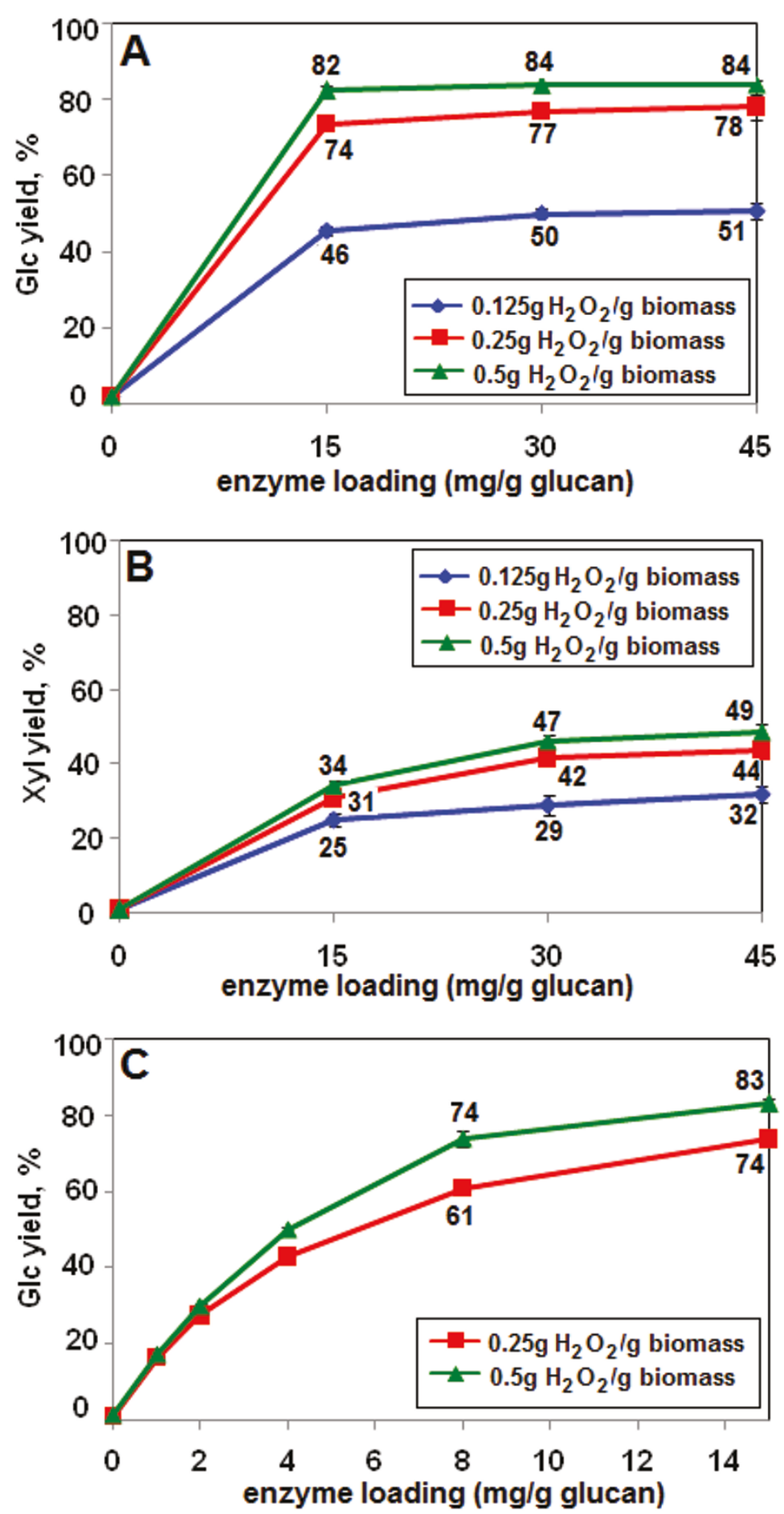

Figure 3 Glucose (Glc) and xylose (Xyl) yields as a function of $\mathrm{H}_{2} \mathrm{O}_{2}$ and enzyme loading. In panels (a) and (b), the enzyme loadings ranged from 0 to $45 \mathrm{mg} / \mathrm{g}$ glucan. In panel (c), the enzyme loading ranged from 0 to $15 \mathrm{mg} / \mathrm{g}$ glucan. Pretreatment biomass loading was 10\%, residence time was $24 \mathrm{~h}$, and enzyme digestion time was $48 \mathrm{~h}$. Glc (a and c) and Xyl (b) yield values indicate yield as a percentage of total measured monomeric Glc and Xyl content of the biomass. Numbers next to the data points are the Glc or Xyl yields (y axis values). The enzyme was Accellerase 1000. 
Table 1 Optimization of mixtures of four commercial enzymes for monomeric glucose (Glc) and xylose (Xyl) release from corn stover pretreated by alkaline hydrogen peroxide (AHP) or ammonia fiber expansion (AFEX)

\begin{tabular}{|c|c|c|c|c|c|c|c|}
\hline \multirow[t]{2}{*}{ Pretreatment } & \multirow[t]{2}{*}{ Optimization } & \multicolumn{4}{|c|}{ Optimal enzyme proportions (\%) } & \multicolumn{2}{|c|}{ Glc or Xyl yield (\%) } \\
\hline & & Acc 1000 & Multifect xylanase & Multifect pectinase & Novozyme 188 & MP & Exptl \\
\hline $0.125 \mathrm{~g} \mathrm{H}_{2} \mathrm{O}_{2} / \mathrm{g}$ biomass & Glc & 59 & 25 & 16 & 0 & 54.0 & $55.0 \pm 1.3$ \\
\hline $0.25 \mathrm{~g} \mathrm{H}_{2} \mathrm{O}_{2} / \mathrm{g}$ biomass & $\mathrm{Glc}$ & 63 & 14 & 21 & 2 & 86.0 & $83.0 \pm 1.0$ \\
\hline \multirow[t]{2}{*}{$0.5 \mathrm{~g} \mathrm{H}_{2} \mathrm{O}_{2} / \mathrm{g}$ biomass } & $\mathrm{Glc}$ & 64 & 9 & 27 & 0 & 99.6 & $95.0 \pm 2.4$ \\
\hline & Xyl & 36 & 19 & 45 & 0 & 74.0 & $75.1 \pm 0.9$ \\
\hline \multirow[t]{2}{*}{ AFEX } & Glc & 66 & 34 & 0 & 0 & 62.0 & $61.5 \pm 1.5$ \\
\hline & $\mathrm{xyl}$ & 40 & 10 & 50 & 0 & 55.7 & $53.4 \pm 2.1$ \\
\hline
\end{tabular}

For all AHP experiments, pretreatment biomass loading was $10 \%$ and pretreatment time was $24 \mathrm{~h}$ with no pH adjustment during the pretreatment. For AFEX pretreatment conditions see Methods. Enzyme loading was $15 \mathrm{mg} / \mathrm{g}$ glucan and digestion time was $48 \mathrm{~h}$. Glc and Xyl values indicate yield as a percentage of total measured monomeric Glc and Xyl content of the biomass. Raw data and statistical analysis are shown in Additional file 1, Supplementary Tables S4-S8. Acc $1000=$ Accellerase 1000; Exptl $=$ experimental results (mean $\pm 1 \mathrm{SD}, \mathrm{n}=8$ ); MP = model prediction.
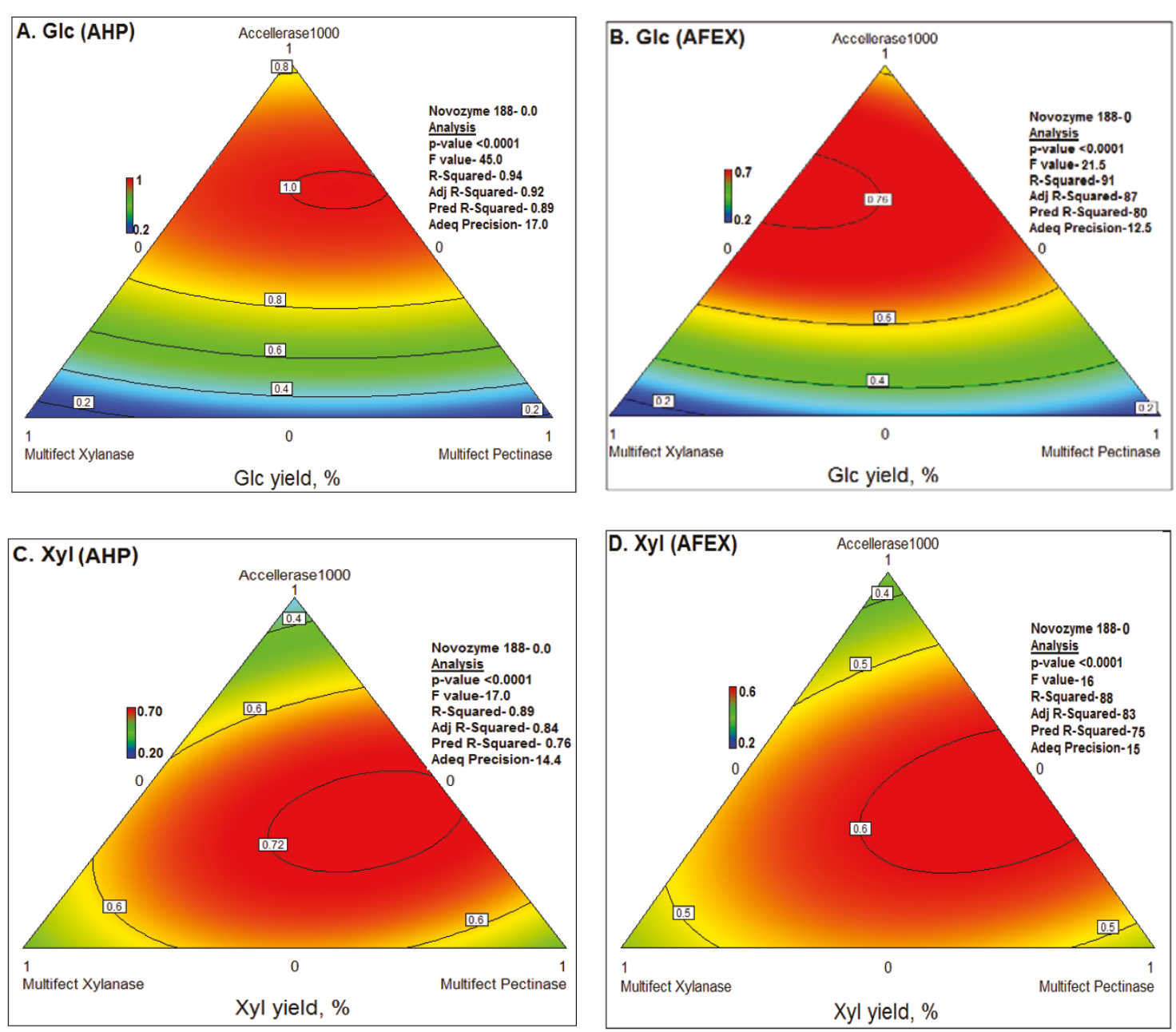

Figure 4 Ternary diagrams for optimization of mixtures of four commercial enzymes for release of glucose (Glc; (a) and (b)) or xylose (Xyl; (c) and (d)) from alkaline hydrogen peroxide (AHP)-pretreated ((a) and (c)) or ammonia fiber expansion (AFEX)-pretreated ((b) and (d)) corn stover. Glc and Xyl yield values indicate yield as a percentage of total measured monomeric Glc and Xyl content of the biomass. The data on which the ternary diagrams are based are from the same experiment shown in Table 1. 


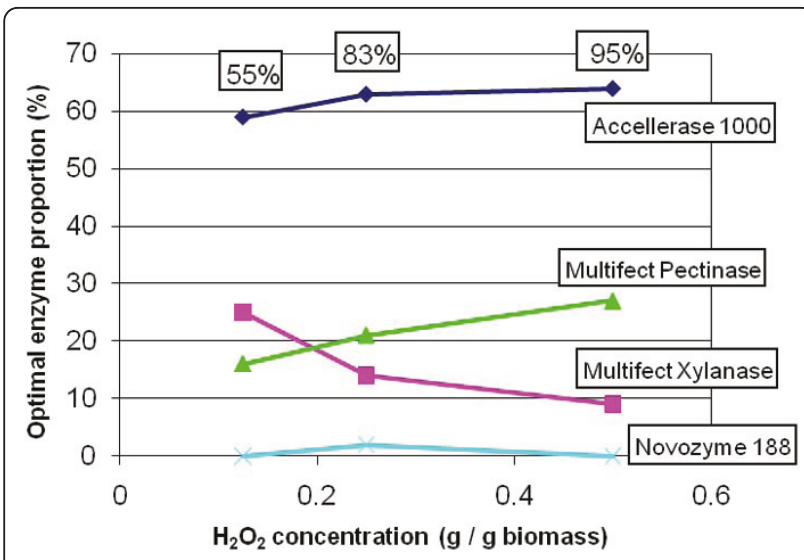

Figure 5 Optimal proportions of four commercial enzymes as a function of $\mathrm{H}_{2} \mathrm{O}_{2}$ loading during alkaline hydrogen peroxide (AHP) pretreatment. The data are from Table 1. Boxed percentages across the top of the graph are the glucose (Glc) yields at each $\mathrm{H}_{2} \mathrm{O}_{2}$ loading, expressed as a percentage of the total measured monomeric Glc in the biomass.

Digestions were performed for $24 \mathrm{~h}$ or $48 \mathrm{~h}$. In $24 \mathrm{~h}$, stover pretreated with $0.5 \mathrm{~g} \mathrm{H}_{2} \mathrm{O}_{2} / \mathrm{g}$ biomass at $10 \%$ loading released $83 \%$ of available Glc at an enzyme loading of $15 \mathrm{mg} / \mathrm{g}$ glucan (Figure 6a) compared to $71 \%$ with Accellerase 1000 alone (Figure 2c). In 48 h, 95\% of the available Glc was released with an optimized enzyme mixture at $15 \mathrm{mg} / \mathrm{g}$ glucan (Figure $6 \mathrm{~b}$ ), compared to $82 \%$ with Accellerase 1000 alone (Figure 2d). When analyzed in parallel, the commercial enzyme mixture optimized for AFEX pretreatment (Table 1) gave $60 \%$ or $62 \%$ of maximum Glc release in $24 \mathrm{~h}$ or $48 \mathrm{~h}$, respectively, and did not exceed $74 \%$ even at the highest enzyme loading of $45 \mathrm{mg} / \mathrm{g}$ glucan (Figure 6c). With less severe AFEX conditions, as specified in Banerjee et al. [20], the same optimized commercial mixture gave a Glc yield of $60.3 \pm 1.8 \%$ in $48 \mathrm{~h}$.

\section{Synthetic mixtures optimized for AHP}

Synthetic mixtures of pure enzymes can reveal the relative importance of specific enzymes in a way that mixtures of incompletely defined commercial enzymes cannot [31,32]. We showed that an optimized synthetic mixture containing 11 components released $52 \%$ and $41 \%$ of available Glc and Xyl, respectively, from AFEXstover, and $69 \%$ and $55 \%$ of available Glc and $\mathrm{Xyl}$, respectively, from stover treated with AHP at $2 \%$ biomass loading and $0.5 \mathrm{~g} \mathrm{H}_{2} \mathrm{O}_{2} / \mathrm{g}$ biomass [20]. Using GENPLAT, we determined the optimal proportions of the same 11 enzymes for hydrolysis of AHP-stover pretreated at $10 \%$ biomass loading and the same $\mathrm{H}_{2} \mathrm{O}_{2}$ loading of $0.5 \mathrm{~g} / \mathrm{g}$ (Figure 7). The optimized mixture released $84.6 \pm 1.3 \%$ of available Glc and $64.7 \pm 2.6 \%$ of available Xyl. That is, the synthetic mixture showed the same trend seen with Accellerase 1000 alone or an optimized four-component commercial mixture of giving higher Glc yields at higher biomass loading (Figure 1 and Table 1). The relevant raw data are shown in Additional file 1, Table S9 and the statistics for the 11-component model in Additional file 1, Table S10.

We earlier optimized a 16-component mixture for AHP-corn stover pretreated at $2 \%$ biomass loading and a loading of $0.5 \mathrm{~g} \mathrm{H}_{2} \mathrm{O}_{2} / \mathrm{g}$ biomass [20]. In the current experiment, we optimized an 11-component mixture. Because in both the earlier [20] and the current (Figure 7) experiments only eight enzymes influenced Glc yield (that is, the others had an optimal proportion of $0 \%$ ), the two sets of results are comparable. Although the only difference between the earlier and current experiments was the use of a higher biomass loading (10\% vs $2 \%$ ), the optimal proportions of some of the enzymes changed rather dramatically. In particular, the optimal proportion of $\mathrm{CBH} 1$ decreased from $31 \%$ to $19 \%$, and the optimal proportion of $\mathrm{CBH} 2$ decreased from $12 \%$ to $4 \%$. That is, the total CBH proportion declined from $43 \%$ to $23 \%$. In contrast, the optimal proportion of endoglucanase (EG1) increased from $8 \%$ to $14 \%$, and the optimum proportion of $\beta$-glucosidase (BG) increased from $5 \%$ to $18 \%$. One possible explanation for these observations is that AHP reduces cellulose crystallinity or otherwise renders the cellulose more susceptible to hydrolysis by the enzymes that are responsible for disrupting the cellulose crystallinity, namely, $\mathrm{CBH} 1$ and $\mathrm{CBH} 2$, making these two enzymes proportionally less important than EG1 and BG $[17,36]$. By this hypothesis, higher biomass loadings are effectively increasing the severity of the AHP pretreatment (due to the increased molar concentration of $\mathrm{H}_{2} \mathrm{O}_{2}$ and $\mathrm{NaOH}$ ), leading to progressively greater cellulose susceptibility to $\mathrm{CBH}$. As this occurs, the limiting factor in the pathway of conversion of cellulose to Glc shifts from decrystallization (catalyzed by $\mathrm{CBH} 1$ and $\mathrm{CBH} 2$ ) to hydrolysis of noncrystalline glucan (catalyzed by EG and BG). Insofar as action on crystalline cellulose is the generally rate-limiting step in overall cellulose hydrolysis, this hypothesis is consistent with the increased Glc yields observed at higher biomass loadings.

An alternative reason for why a higher proportion of BG is needed at $10 \%$ pretreatment loading compared to $2 \%$ might be a result of the higher Glc yields seen at the higher loading. As the rate of cellulose hydrolysis by $\mathrm{CBH} 1, \mathrm{CBH} 2$, and EG1 increases, cellobiose concentrations would rise, leading to more feedback inhibition by cellobiose. At a total glucan concentration of $2 \mathrm{mg} / \mathrm{ml}$ and with $87 \%$ conversion of glucan to cellobiose, the cellobiose concentration in our samples could attain a theoretical maximum concentration of $4.8 \mathrm{mM}$, which is within the range known to inhibit $\mathrm{CBH} 1$ and possibly 

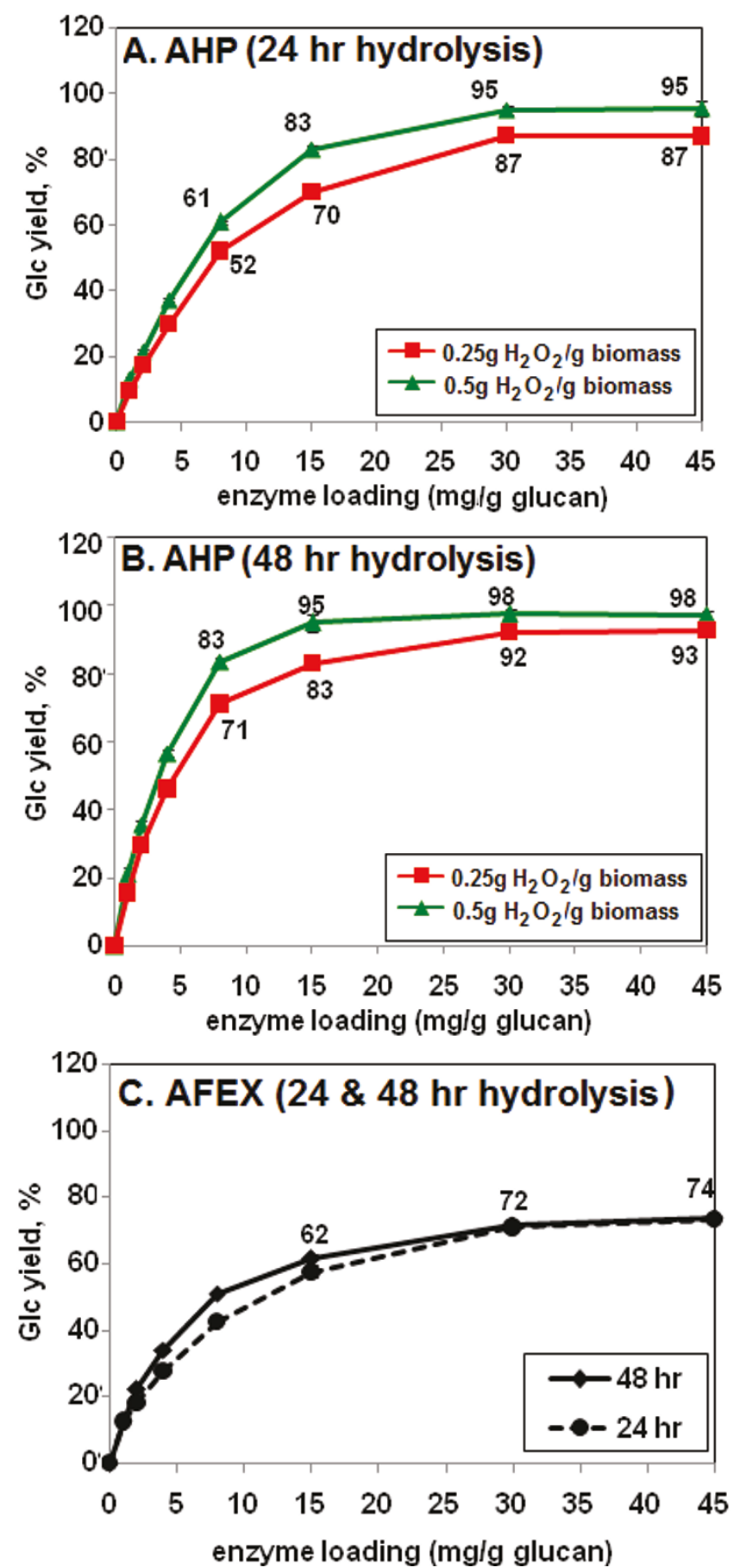

Figure 6 Glucose (Glc) yield as a function of enzyme loading for different pretreatment conditions, $\mathrm{H}_{2} \mathrm{O}_{2}$ loadings, and enzyme hydrolysis times. The enzymes used for the hydrolysis were mixtures of four commercial enzymes as established for each specific pretreatment condition (that is, $\mathrm{H}_{2} \mathrm{O}_{2}$ loading) at an enzyme loading of $15 \mathrm{mg} / \mathrm{g}$ glucan and $48 \mathrm{~h}$ hydrolysis (see Table 1). (a) Alkaline hydrogen peroxide (AHP) pretreatment and $24 \mathrm{~h}$ enzyme hydrolysis. (b) AHP pretreatment and $48 \mathrm{~h}$ digestion. (c) Ammonia fiber expansion (AFEX) pretreatment, 24 $\mathrm{h}$ and $48 \mathrm{~h}$ enzyme hydrolysis. Biomass loading during the AHP pretreatment was $10 \%$. For AFEX conditions see Methods. All biomass loadings in the enzyme hydrolysis step were $0.2 \%$ glucan. Glc yield values indicate yield as a percentage of total measured monomeric Glc content of the biomass. Numbers next to the data points are the Glc yields (y axis values). 
also EG1 [37]. Therefore, as the cellobiose concentration in the reaction mixture approaches inhibitory levels, BG would be predicted to become more important for optimal Glc yields, as was observed (Figure 7).

\section{Further improvements of AHP}

Several factors were examined that might further improve the efficiency of AHP. These were $\mathrm{pH}$ stabilization, extended residence time, and yet higher biomass loadings.
An $\mathrm{H}_{2} \mathrm{O}_{2}$ loading of $0.125 \mathrm{~g} / \mathrm{g}$ biomass was less effective than either 0.25 or $0.5 \mathrm{~g} \mathrm{H}_{2} \mathrm{O}_{2} / \mathrm{g}$ biomass (Figure 3). However, at an $\mathrm{H}_{2} \mathrm{O}_{2}$ loading of $0.125 \mathrm{~g} / \mathrm{g}$ biomass, the $\mathrm{pH}$ tended to drift downward from the optimum of 11.5 over the course of a $24 \mathrm{~h}$ pretreatment. This $\mathrm{pH}$ drift did not occur at 0.25 or $0.5 \mathrm{~g} \mathrm{H}_{2} \mathrm{O}_{2} / \mathrm{g}$ biomass. Therefore, we tested whether stabilizing the $\mathrm{pH}$ at 11.5 would improve the effectiveness of AHP pretreatment at lower $\mathrm{H}_{2} \mathrm{O}_{2}$ loadings. When the $\mathrm{pH}$ of an AHP pretreatment at $10 \%$ biomass loading and $0.125 \mathrm{~g} \mathrm{H}_{2} \mathrm{O}_{2} / \mathrm{g}$ biomass
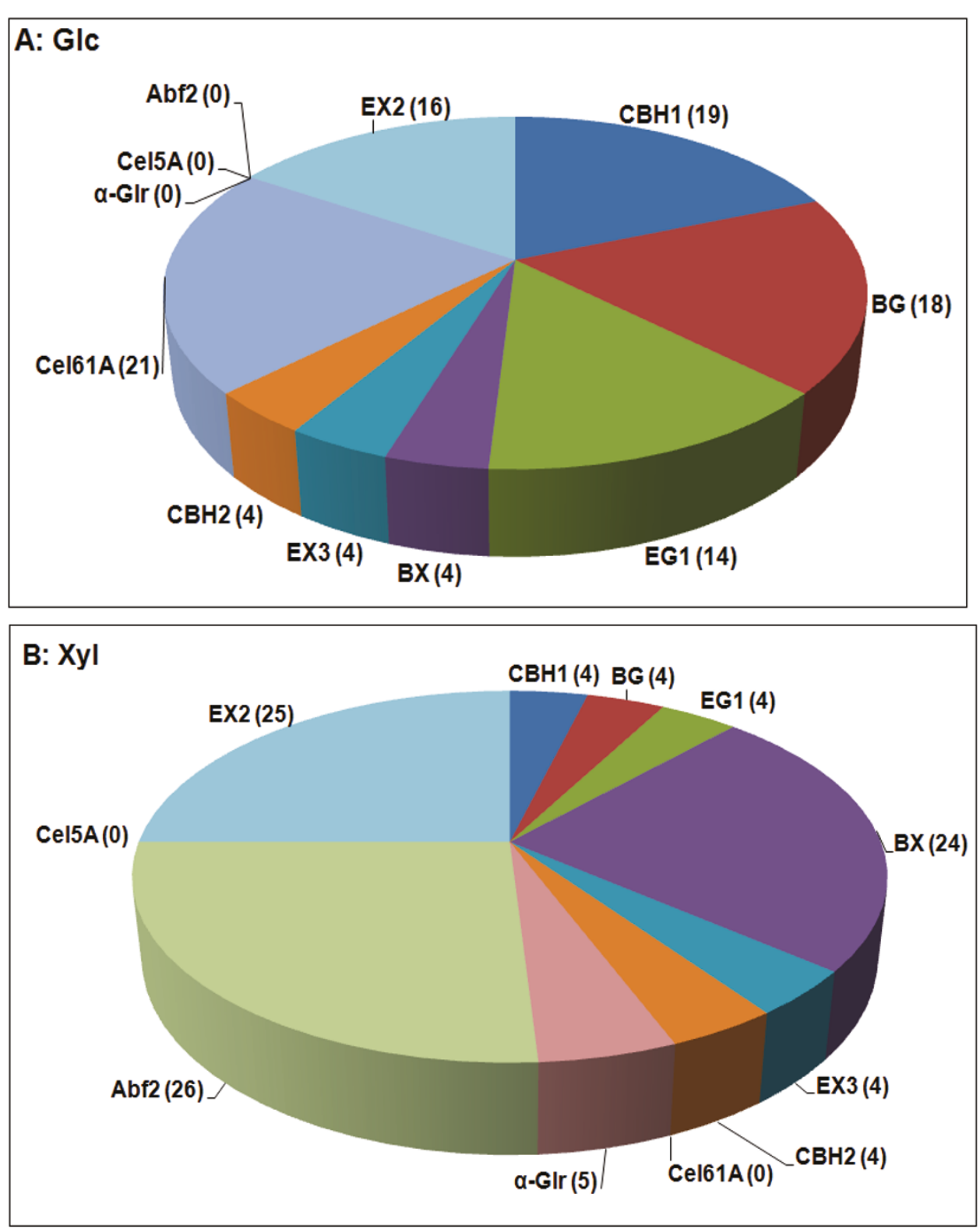

Figure 7 Optimization of an 11-component synthetic enzyme mixture for (a) glucose (Glc) or (b) xylose (Xyl) yields from alkaline hydrogen peroxide (AHP)-corn stover. AHP conditions were 10\% biomass loading, $0.5 \mathrm{~g} \mathrm{H}_{2} \mathrm{O}_{2} / \mathrm{g}$ biomass, $24 \mathrm{~h}$ pretreatment, and $48 \mathrm{~h}$ enzymatic hydrolysis. Raw data and statistical analysis are shown in Additional file 1, Tables S9 and S10. 
was held constant by manually readjusting the $\mathrm{pH}$ back to 11.5 every $6 \mathrm{~h}$ with $5 \mathrm{M} \mathrm{NaOH}$, subsequent yields of monomeric Glc improved from $46 \%$ to $59 \%$ (using Accellerase 1000 at $15 \mathrm{mg} / \mathrm{g}$ glucan) (Figure 8). With a four-component enzyme mixture optimized specifically for this pretreatment condition, the Glc yields could be further increased to $73.8 \%$ (Table 2).

The effect of extended residence time was also reinvestigated. Gould $[15,29]$ reported that AHP pretreatment of $2 \%$ biomass with $0.5 \mathrm{~g} \mathrm{H}_{2} \mathrm{O}_{2} / \mathrm{g}$ biomass was essentially complete at $8 \mathrm{~h}$. At a biomass loading of approximately $8.6 \%(\mathrm{w} / \mathrm{v})$ and an $\mathrm{H}_{2} \mathrm{O}_{2}$ loading of approximately $0.25 \mathrm{~g} / \mathrm{g}$ biomass, Saha and Cotta [22] found that AHP pretreatment was essentially complete at $6 \mathrm{~h}$. However, neither of these studies examined the effect of extended residence time at low $\mathrm{H}_{2} \mathrm{O}_{2}$ loadings. In fact, extending the residence time from $24 \mathrm{~h}$ to $48 \mathrm{~h}$ at a low $\mathrm{H}_{2} \mathrm{O}_{2}$ loading ( $0.125 \mathrm{~g} / \mathrm{g}$ biomass), with no $\mathrm{pH}$ adjustment, caused an increase in Glc yields in response to Accellerase 1000 from $46 \%$ to $58 \%$ (Figure 8). With a four-component enzyme mixture optimized specifically for this pretreatment condition, Glc yields could be increased further to $66.3 \%$ (Table 2). In summary, with Accellerase 1000 alone, $\mathrm{pH}$ adjustment or extended residence time caused a similar enhancement of monomeric Glc yields (that is, from $46 \%$ up to $58 \%$ to $59 \%$ ), but when using an optimized commercial cocktail, $\mathrm{pH}$ adjustment caused a bigger enhancement than increased pretreatment time (that is, from $66 \%$ to $74 \%$ ) (Figure 8 and Table 2).

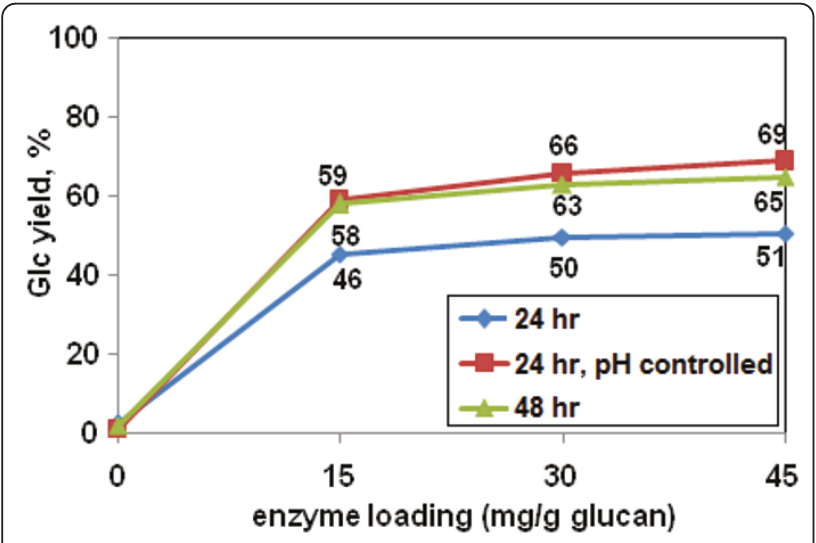

Figure 8 Improvement in glucose (GIc) yield with $\mathrm{pH}$ adjustment or extended residence time. Biomass loading was $10 \%, \mathrm{H}_{2} \mathrm{O}_{2}$ loading was $0.125 \mathrm{~g} / \mathrm{g}$ biomass, and enzyme digestion was Accellerase 1000 for $48 \mathrm{~h}$. Varied conditions were time of pretreatment ( $24 \mathrm{~h}$ or $48 \mathrm{~h}$ ), and with or without periodic $\mathrm{pH}$ readjustment to 11.5 ('pH controlled') during the pretreatment. Glc yield values indicate yield as a percentage of total measured monomeric Glc content of the biomass. Numbers next to the data points are the Glc yields ( $y$ axis values).
In regard to biomass loading during pretreatment, the earlier results indicated that $10 \%$ loading was superior to $2 \%, 6 \%$, or $8 \%$ (Figures 1 and 2). Therefore, even higher loadings were tested. At loadings of $15 \%$ or $20 \%$, with subsequent digestion with Accellerase 1000 alone, sugar yields improved modestly, by $4 \%$ to $8 \%$ for Glc and 3\% to 5\% for Xyl (Figure 9).

Finally, several of these enhanced conditions, that is, high biomass loading (15\%), low $\mathrm{H}_{2} \mathrm{O}_{2}$ loading $(0.125 \mathrm{~g}$ / $\mathrm{g}$ biomass), extended residence time $(48 \mathrm{~h}), \mathrm{pH}$ adjustment, and optimized enzyme mixtures, were tested together (Table 2). With an optimized four-component mixture of commercial enzymes, a monomeric Glc yield of $76.8 \%$ was attained (Table 2 ).

\section{Discussion}

Our results confirm that AHP is an effective pretreatment of corn stover for subsequent enzymatic saccharification to monomeric Glc and Xyl, and that it can be further improved in performance and economics by increasing the biomass loading, reducing the $\mathrm{H}_{2} \mathrm{O}_{2}$ loading, extending the pretreatment time, and maintaining the $\mathrm{pH}$.

The advantages of AHP over other existing effective pretreatments are several. First, it uses readily available and environmentally benign chemicals, namely, hydrogen peroxide and sodium hydroxide. Second, it operates at low temperature $\left(21^{\circ} \mathrm{C}\right.$ to $\left.50^{\circ} \mathrm{C}\right)$ and atmospheric pressure, so no expensive specialized reactors are necessary. It can be performed in any standard scientific laboratory, which means that researchers interested in studying AHP do not have to rely on outside collaborators with specialized equipment. Third, it is less expensive than two other highly effective pretreatments, ionic liquids and phosphoric acid/organic solvent. Phosphoric acid/ethanol was reported to give a monomeric Glc yield of $>89 \%$ with a very low enzyme loading $(0.66 \mathrm{mg}$ cellulase/g glucan), but it requires a phosphoric acid:biomass loading of approximately 13:1 (w/w) [6,7]. Ionic liquids gave $96 \%$ digestibility of switchgrass but use a reagent: biomass ratio of 32:1 [8]. Practical implementation of these two effective pretreatments will require highly efficient recycling of the respective reagents.

The main potential disadvantages of AHP pretreatment are the cost of $\mathrm{H}_{2} \mathrm{O}_{2}$ and the presence of significant residual salt. At an $\mathrm{H}_{2} \mathrm{O}_{2}$ price of US $\$ 0.80$ to $\$ 1.00 / \mathrm{kg}$ (on a $100 \%$ basis) (Dr Philip Block, FMC Corporation, personal communication), the current cost for processing 1 metric ton of biomass would be US\$102 to US $\$ 125$ at an $\mathrm{H}_{2} \mathrm{O}_{2}$ loading of $0.125 \mathrm{~g} / \mathrm{g}$ biomass, plus US\$36 for $\mathrm{NaOH}$ (at $\$ 300 /$ ton). However, AHP can probably be improved to operate at even lower $\mathrm{H}_{2} \mathrm{O}_{2}$ loadings, for example, by $\mathrm{H}_{2} \mathrm{O}_{2}$ stabilization, improved $\mathrm{pH}$ control, or $\mathrm{H}_{2} \mathrm{O}_{2}$ recycling [15]. The use of lower 
Table 2 Optimization of mixtures of four commercial enzymes for different alkaline hydrogen peroxide (AHP) pretreatments

\begin{tabular}{|c|c|c|c|c|c|c|}
\hline \multirow[t]{2}{*}{ Pretreatment conditions } & \multicolumn{4}{|c|}{ Optimal enzyme proportions (\%) } & \multicolumn{2}{|c|}{ Glc yield (\%) } \\
\hline & $\begin{array}{l}\text { Acc } \\
1000\end{array}$ & $\begin{array}{l}\text { Multifect } \\
\text { xylanase }\end{array}$ & $\begin{array}{l}\text { Multifect } \\
\text { pectinase }\end{array}$ & $\begin{array}{l}\text { Novozyme } \\
188\end{array}$ & MP & Exptl \\
\hline $\begin{array}{l}0.125 \mathrm{~g} \mathrm{H}_{2} \mathrm{O}_{2} / \mathrm{g} \text { biomass ( } 10 \% \text { biomass loading, } 24 \mathrm{~h} \text {, controlled } \\
\mathrm{pH} \text { ) }\end{array}$ & 63 & 24 & 13 & 0 & 72 & $\begin{array}{l}73.8 \pm \\
2.2\end{array}$ \\
\hline $\begin{array}{l}0.125 \mathrm{~g} \mathrm{H}_{2} \mathrm{O}_{2} / \mathrm{g} \text { biomass ( } 10 \% \text { biomass loading, } 48 \mathrm{~h} \text {, no } \mathrm{pH} \\
\text { control) }\end{array}$ & 63 & 14 & 20 & 3 & 66 & $\begin{array}{l}66.3 \pm \\
1.3\end{array}$ \\
\hline $\begin{array}{l}0.5 \mathrm{~g} \mathrm{H}_{2} \mathrm{O}_{2} / \mathrm{g} \text { biomass (15\% biomass loading, } 24 \mathrm{~h} \text {, no pH } \\
\text { control) }\end{array}$ & 63 & 10 & 27 & 0 & 100 & $\begin{array}{l}96.1 \pm \\
2.1\end{array}$ \\
\hline $\begin{array}{l}0.5 \mathrm{~g} \mathrm{H}_{2} \mathrm{O}_{2} / \mathrm{g} \text { biomass (20\% biomass loading, } 24 \mathrm{~h} \text {, no } \mathrm{pH} \\
\text { control) }\end{array}$ & 63 & 10 & 27 & 0 & 100 & $\begin{array}{l}96.8 \pm \\
1.0\end{array}$ \\
\hline $\begin{array}{l}0.125 \mathrm{~g} \mathrm{H}_{2} \mathrm{O}_{2} / \mathrm{g} \text { biomass ( } 15 \% \text { biomass loading, } 48 \mathrm{~h} \text {, controlled } \\
\mathrm{pH} \text { ) }\end{array}$ & 62 & 24 & 15 & 0 & 76 & $\begin{array}{l}76.8 \pm \\
2.2\end{array}$ \\
\hline
\end{tabular}

All models were optimized for glucose (Glc). Glc values indicate yield as a percentage of total measured Glc content of the biomass. Enzyme loading was 15 mg/ g glucan. Raw data and statistical analysis are shown in Additional file 1, Tables S11-S16.

Acc $1000=$ Accellerase 1000; Exptl $=$ experimental results (mean $\pm 1 \mathrm{SD}, \mathrm{n}=8$ ); MP = model prediction.
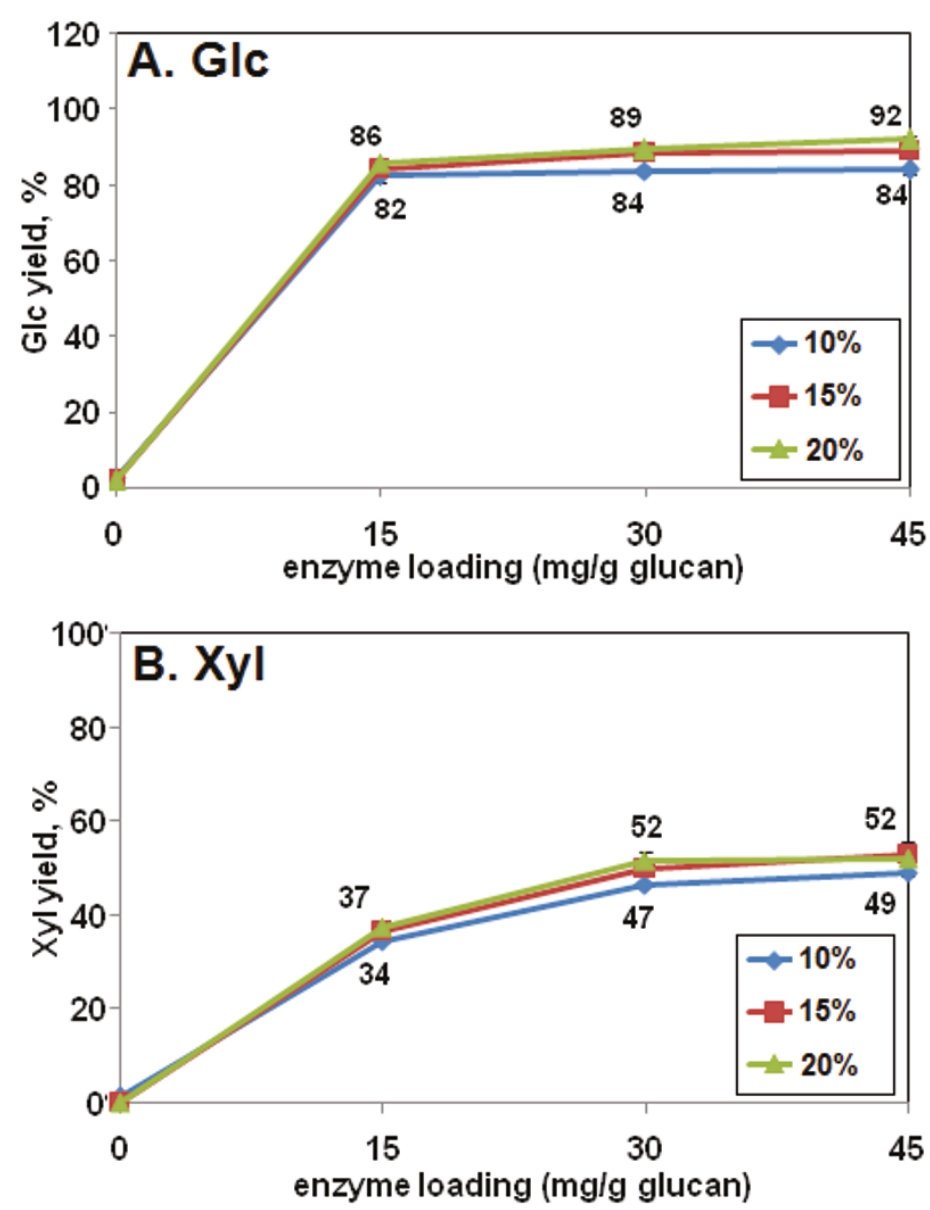

Figure 9 Effect of high biomass loadings on (a) glucose (GIc) and (b) xylose (Xyl) yield from alkaline hydrogen peroxide (AHP)pretreated corn stover. The $\mathrm{H}_{2} \mathrm{O}_{2}$ loading in the AHP pretreatment was $0.5 \mathrm{~g} / \mathrm{g}$ biomass and the residence time was $24 \mathrm{~h}$. The enzyme digestion was $48 \mathrm{~h}$ with Accellerase 1000. Glc and Xyl yields values indicate yield as a percentage of total measured monomeric Glc and Xyl content of the biomass. 
$\mathrm{H}_{2} \mathrm{O}_{2}$ loadings would also have the advantage of reducing the consumption of $\mathrm{NaOH}$ and acid. In addition, it might be possible to reduce the intrinsic cost of $\mathrm{H}_{2} \mathrm{O}_{2}$ by on-site production or by the development of new methods of production [38].

In these and earlier studies, we used an enzyme loading of $15 \mathrm{mg}$ total protein/g glucan as our standard hydrolysis condition. Comparison of this enzyme loading to other studies in which enzyme loadings are expressed in filter paper units (FPU) is difficult because FPU is a measure of cellulase activity only and does not take into account the contribution of the many other enzymes in most cellulase preparations, such as BG and xylanases, to the release of monomeric Glc and Xyl from lignocellulose [31]. However, a point of comparison can be made to Spezyme CP, a widely used commercial cellulase cocktail. It has been reported to contain between 0.3 and $0.48 \mathrm{FPU} / \mathrm{mg}$ protein [35,39], and therefore our standard loading of $15 \mathrm{mg} / \mathrm{g}$ glucan corresponds to a Spezyme CP loading of between 4.5 and $7.2 \mathrm{FPU} / \mathrm{g}$ glucan.

In the current experiments, the biomass was not washed or otherwise separated into multiple processing streams after pretreatment. Many pretreatment protocols involve post-washing the biomass to remove inhibitors and salts. Depending on the type and severity, some pretreatments also remove some of the lignin and hemicelluloses [8,19,23,24,26-28]. However, washing uses a large amount of water (exactly how much is rarely indicated), and, depending on the severity of the pretreatment, removes a proportion of the cellulose and hemicellulose. This lowers the energy content of the biomass and, for laboratory-scale studies, necessitates reanalysis of the glucan and xylan content post pretreatment in order to calculate final sugar yields [19]. In our experiments, all of the original material was still present regardless of the pretreatment severity. Since no cellulose or hemicellulose was lost, reanalysis of the biomass composition was unnecessary. The main disadvantage of not washing after AHP is that the final product contains salt from the $\mathrm{NaOH}$ and $\mathrm{HCl}$. With AHP conditions of $2 \%$ biomass loading and $0.5 \mathrm{~g} \mathrm{H}_{2} \mathrm{O}_{2} / \mathrm{g}$ biomass, the final $\mathrm{NaCl}$ concentration was approximately $200 \mathrm{mM}$ (Additional file 1, Table $\mathrm{S} 1)$. At the highest biomass loading (20\%) and highest $\mathrm{H}_{2} \mathrm{O}_{2}$ loading, the $\mathrm{NaCl}$ concentration was approximately 1.5 M (Additional file 1, Table S1). This high salt concentration was not a problem in our experiments because all enzyme digestions were performed at $0.2 \%$ glucan loading, which lowered the salt concentration to approximately $20 \mathrm{mM}$, but it might become a problem if enzymatic hydrolysis (and fermentation) were performed at industrially relevant high-solids loading.
In addition to lowering the consumption of $\mathrm{H}_{2} \mathrm{O}_{2}$, reducing the $\mathrm{H}_{2} \mathrm{O}_{2}$ loading results in less residual salt in the pretreated material. For example, at $10 \%$ biomass loading and $0.125 \mathrm{~g} \mathrm{H}_{2} \mathrm{O}_{2} / \mathrm{g}$ biomass, the $\mathrm{NaCl}$ concentration in the biomass after neutralization was approximately $350 \mathrm{mM}$ (Additional file 1, Table S1). Saha and Cotta [21,22] used AHP-pretreatment on barley and wheat straw at approximately $10 \%$ biomass loading and approximately $2.5 \% \mathrm{H}_{2} \mathrm{O}_{2}$ and successfully digested and fermented the resulting material without post-washing. Residual salt did, however, inhibit butanol fermentation by Clostridum beijerinckii [40]. Possible routes to alleviating the problem of salt from AHP include further decreasing the $\mathrm{H}_{2} \mathrm{O}_{2}$ loading, removing the salt after pretreatment, or performing the fermentation with salttolerant organisms. Saccharomyces cerevisiae strains able to tolerate $\mathrm{NaCl}$ concentrations of greater than $0.5 \mathrm{M}$ $\mathrm{NaCl}$ have been developed under laboratory conditions [41-43].

Previous studies with AHP have shown that it solubilizes lignin but its effect on cellulose crystallinity is unclear $[17,19,36]$. One or both of these modifications could be contributing to the effectiveness of AHP as a pretreatment. Additional studies on the mechanisms of AHP are needed, for example, on the relative composition of the insoluble and soluble fractions after pretreatment. In the experiments reported here, the soluble and insoluble portions of the biomass were not separated after pretreatment, and therefore the total (free, oligomeric, and polymeric) Glc and Xyl composition of the biomass did not change between the original biomass and the hydrolyzed material.

AHP satisfies many criteria of an ideal pretreatment, in particular high yields of fermentable sugars at low enzyme loadings, low cost of pretreatment reactors, minimal post-pretreatment conditioning, low disposal challenges, and low heat and power demands [4]. Further improvements will be necessary, however, before AHP can be considered an economically relevant pretreatment, in particular a reduction in the cost of hydrogen peroxide.

\section{Conclusions}

Corn stover pretreated by AHP gives high monomeric Glc and Xyl yields at low enzyme loadings. AHP appear to be amenable to further improvements that could lead to its development as an economically viable step in lignocellulose to ethanol conversion.

\section{Additional material}

Additional file 1: Supplementary supporting data. Table S1. Biomass and reagent loadings for experiments described in the paper. Table S2. Amounts of $\mathrm{NaOH}$ added during $\mathrm{pH}$ adjustment experiments. Table S3. 
Compensation calculations for $\mathrm{NaCl}$ (as $\mathrm{NaOH}$ plus $\mathrm{HCl}$ ) added during pretreatment and $\mathrm{pH}$ neutralization. Table S4. Experimental results for glucose (Glc) optimization obtained from digestion of alkaline hydrogen peroxide (AHP)-treated corn stover $\left(0.125 \mathrm{~g} \mathrm{H}_{2} \mathrm{O}_{2} / \mathrm{g}\right.$ biomass, $10 \%$ solids loading). Table S5. Experimental results for Glc optimization obtained from digestion of AHP-treated corn stover $\left(0.25 \mathrm{~g} \mathrm{H}_{2} \mathrm{O}_{2} / \mathrm{g}\right.$ biomass, $10 \%$ solids loading). Table S6. Experimental results for Glc optimization obtained from digestion of AHP-treated corn stover $\left(0.5 \mathrm{~g} \mathrm{H}_{2} \mathrm{O}_{2} / \mathrm{g}\right.$ biomass, 10\% solids loading). Table S7. Experimental results for Glc and xylose (Xyl) optimization obtained from digestion of ammonia fiber expansion (AFEX)-treated corn stover with mixtures of four commercial enzyme preparations. Table S8. Statistical analysis for Glc and Xyl optimization from AHP and AFEX-treated corn stover. Table S9. Experimental results for Glc and Xyl optimization obtained from digestion of AHP-treated corn stover $\left(0.5 \mathrm{~g} \mathrm{H}_{2} \mathrm{O}_{2} / \mathrm{g}\right.$ biomass) with 11component synthetic enzyme mixture. Table S10. Statistical analysis of the 11-component optimization experiment. Table S11. Experimental results for Glc optimization obtained from digestion of AHP-treated corn stover $\left(0.125 \mathrm{~g} \mathrm{H}_{2} \mathrm{O}_{2} / \mathrm{g}\right.$ biomass, $10 \%$ solids loading with controlled $\mathrm{pH}$ for $24 \mathrm{~h}$ ). Table S12. Experimental results for Glc optimization obtained from digestion of AHP-treated corn stover $\left(0.125 \mathrm{~g} \mathrm{H}_{2} \mathrm{O}_{2} / \mathrm{g}\right.$ biomass, $10 \%$ solids loading for $48 \mathrm{~h}$ and no $\mathrm{pH}$ control). Table S13. Experimental results for Glc optimization obtained from digestion of AHP-treated corn stover ( $0.5 \mathrm{~g} \mathrm{H}_{2} \mathrm{O}_{2} / \mathrm{g}$ biomass, $15 \%$ solids loading, $24 \mathrm{~h}$, no $\mathrm{pH}$ control). Table S14. Experimental results for Glc optimization obtained from digestion of AHP-treated corn stover $\left(0.5 \mathrm{~g} \mathrm{H}_{2} \mathrm{O}_{2} / \mathrm{g}\right.$ biomass, $20 \%$ solids loading, $24 \mathrm{~h}$, no $\mathrm{pH}$ control). Table S15. Experimental results for Glc optimization obtained from digestion of AHP-treated corn stover $(0.125 \mathrm{~g}$ $\mathrm{H}_{2} \mathrm{O}_{2} / \mathrm{g}$ biomass, $15 \%$ solids loading, $48 \mathrm{~h}$, controlled $\mathrm{pH}$ ). Table $\mathrm{S} 16$ Statistical analysis for Glc optimization from corn stover under different AHP conditions.

\section{Acknowledgements}

We thank Nick Santoro (GLBRC, MSU) and Ken Keegstra (DOE Plant Research Laboratory and GLBRC, MSU) for discussions, Melissa Borrusch and Shane Cantu for technical support, and the laboratory of Bruce Dale (Department of Chemical Engineering, MSU) for the AFEX-treated corn stover. This work was funded by the US Department of Energy Great Lakes Bioenergy Research Center (GLBRC) (DOE Office of Science BER DE-FC02-07ER64494) and by grant DE-FG02-91ER200021 to the Plant Research Laboratory from the US Department of Energy, Office of Basic Energy Sciences, Division of Chemical Sciences, Geosciences and Biosciences.

\section{Author details}

'Department of Energy, Great Lakes Bioenergy Research Center, Michigan State University, East Lansing, MI, USA. ${ }^{2}$ Department of Chemical Engineering and Materials Science, Michigan State University, East Lansing, MI, USA.

${ }^{3}$ Department of Energy, Plant Research Laboratory, Michigan State University, East Lansing, MI, USA.

\section{Authors' contributions}

GB and SC performed the alkaline peroxide pretreatments, designed and executed the digestion experiments, performed the statistical analyses and helped write the paper; JSC cloned genes and expressed proteins; DBH made conceptual contributions and helped write the paper; JDW contributed to experimental design and drafted the final manuscript. All authors read and approved the final manuscript.

\section{Competing interests}

The authors declare that they have no competing interests.

Received: 20 December 2010 Accepted: 9 June 2011 Published: 9 June 2011

\section{References}

1. Mosier N, Wyman C, Dale B, Elander R, Lee YY, Holtzapple M, Ladisch M: Features of promising technologies for pretreatment of lignocellulosic biomass. Bioresour Technol 2005, 96:673-686.
2. da Costa Sousa L, Chundawat SP, Balan V, Dale BE: 'Cradle-to-grave' assessment of existing lignocellulose pretreatment technologies. Curr Opin Biotechnol 2009, 20:1-9.

3. Wyman CE, Dale BE, Elander RT, Holtzapple M, Ladisch MR, Lee YY: Comparative sugar recovery data from laboratory scale application of leading pretreatment technologies to corn stover. Bioresour Technol 2005, 96:2026-2032.

4. Yang B, Wyman CE: Pretreatment: the key to unlocking low-cost cellulosic ethanol. Biofuels Bioproducts Biorefining 2007, 2:26-40.

5. Farone WA, Cuzens JE: Strong acid hydrolysis of cellulosic and hemicellulosic materials Washington, DC: US Patent Office; 1997, US Patent 5,597,714..

6. Sathitsuksanoh N, Zhu Z, Ho TJ, Bai MD, Zhang YH: Bamboo saccharification through cellulose solvent-based biomass pretreatment followed by enzymatic hydrolysis at ultra-low cellulase loadings. Bioresour Technol 2010, 101:4926-4929.

7. Sathitsuksanoh N, Zhu Z, Templeton N, Rollin JA, Harvey SP, Zhang YHP: Saccharification of a potential bioenergy crop, Phragmites australis (common reed), by lignocellulose fractionation followed by enzymatic hydrolysis at decreased cellulase loadings. Ind Eng Chem Res 2009, 48:6441-6447.

8. Li C, Knierim B, Manisseri C, Arora R, Scheller HV, Auer M, Vogel KP, Simmons BA, Singh S: Comparison of dilute acid and ionic liquid pretreatment of switchgrass: biomass recalcitrance, delignification and enzymatic saccharification. Bioresour Technol 2010, 101:4900-4906.

9. Lau MW, Dale BE: Cellulosic ethanol production from AFEX-treated corn stover using Saccharomyces cerevisiae 424A(LNH-ST). Proc Natl Acad Sci USA 2009, 106:1368-1373.

10. Gupta R, Lee YY: Pretreatment of hybrid poplar by aqueous ammonia. Biotechnol Prog 2009, 25:357-364.

11. Pan X, Arato C, Gilkes N, Gregg D, Mabee W, Pye K, Xiao Z, Zhang X, Saddler J: Biorefining of softwoods using ethanol organosolv pulping: preliminary evaluation of process streams for manufacture of fuel-grade ethanol and co-products. Biotechnol Bioengineer 2005, 90:473-481.

12. McGinnis GD, Wilson WW, Mullen CE: Biomass pre-treatment with water and high pressure oxygen: the wet-oxidation process. Ind Eng Chem Prod Res Dev 1983, 22:352-357.

13. Chang VS, Nagwami M, Kim CH, Holtzapple MT: Oxidative lime pretreatment of high-lignin biomass: poplar wood and newspaper. Appl Biochem Biotechnol 2001, 94:1-28.

14. Palonen $\mathrm{H}$, Thomsen $\mathrm{AB}$, Tenkanen M, Schmidt AS, Viikari L: Evaluation of wet oxidation pretreatment for enzymatic hydrolysis of softwood. Appl Biochem Biotechnol 2004, 117:1-17.

15. Gould JM: Alkaline peroxide delignification of agricultural residues to enhance enzymatic saccharification. Biotechnol Bioengineer 1984, 26:46-52.

16. Gould JM, Freer SN: High-efficiency ethanol production from lignocellulosic residues pretreated with alkaline $\mathrm{H}_{2} \mathrm{O}_{2}$. Biotechnol Bioengineer 1984, 26:628-631.

17. Gould JM: Studies on the mechanism of alkaline peroxide delignification of agricultural residues. Biotechnol Bioengineer 1985, 27:225-231.

18. Kerley MS, Fahey GC Jr, Berger LL, Gould JM, Baker FL: Alkaline hydrogen peroxide treatment unlocks energy in agricultural by-products. Science 1985, 230:820-822

19. Selig MJ, Vinzant TB, Himmel ME, Decker SR: The effect of lignin removal by alkaline peroxide pretreatment on the susceptibility of corn stover to purified cellulolytic and xylanolytic enzymes. Appl Biochem Biotechnol 2009, 155:397-406

20. Banerjee G, Car S, Scott-Craig JS, Borrusch MS, Walton JD: Rapid optimization of enzyme mixtures for deconstruction of diverse pretreatment/biomass feedstock combinations. Biotechnol Biofuels 2010, 3:22.

21. Saha BC, Cotta MA: Comparison of pretreatment strategies for enzymatic saccharification and fermentation of barley straw to ethanol. New Biotechnol 2010, 27:10-15.

22. Saha BC, Cotta MA: Ethanol production from alkaline peroxide pretreated enzymatically saccharified wheat straw. Biotechnol Prog 2006, 22:449-453.

23. Qi B, Chen X, Shen F, Su Y, Wan Y: Optimization of enzymatic hydrolysis of wheat straw pretreated by alkaline peroxide using response surface methodology. Ind Eng Chem Res 2009, 48:7346-7353.

24. Yamashita Y, Shono M, Sasaki C, Nakamura Y: Alkaline peroxide pretreatment for efficient enzymatic saccharification of bamboo. Carbohydr Polymers 2009, 79:914-920. 
25. Patel MM, Bhatt RM: Optimisation of the alkaline peroxide pretreatment for the delignification of rice straw and its applications. J Chem Tech Biotechnol 1992, 53:253-263.

26. Yang B, Boussaid A, Mansfield SD, Gregg DJ, Saddler JN: Fast and efficient alkaline peroxide treatment to enhance the enzymatic digestibility of steam-exploded softwood substrates. Biotechnol Bioengineer 2002, 77:678-684.

27. Rabelo SC, Filho RM, Costa AC: A comparison between lime and alkaline hydrogen peroxide pretreatments of sugarcane bagasse for ethanol production. Appl Biochem Biotechnol 2008, 148:45-58.

28. Wang B, Wang X, Feng H: Deconstructing recalcitrant Miscanthus with alkaline peroxide and electrolyzed water. Bioresour Technol 2010, 101:752-760.

29. Gould JM: Enhanced polysaccharide recovery from agricultural residues and perennial grasses treated with alkaline hydrogen peroxide. Biotechnol Bioengineer 1985, 27:893-896.

30. Gould JM, Jasberg BK, Fahey GC Jr, Berger LL: Treatment of wheat straw with alkaline hydrogen peroxide in a modified extruder. Biotechnol Bioengineer 1989, 33:233-236.

31. Banerjee G, Car S, Scott-Craig JS, Borrusch MS, Bongers M, Walton JD: Synthetic multi-component enzyme mixtures for deconstruction of lignocellulosic biomass. Bioresour Technol 2010, 101:9097-9105.

32. Banerjee G, Car S, Scott-Craig JS, Borrusch MS, Aslam N, Walton JD: Synthetic enzyme mixtures for biomass deconstruction: production and optimization of a core set. Biotechnol Bioengineer 2010, 106:707-720.

33. Chundawat SPS, Venkatesh B, Dale BE: Effect of particle size based separation of milled corn stover on AFEX pretreatment and enzymatic digestibility. Biotechnol Bioengineer 2007, 96:219-231.

34. Jeoh T, Ishizawa Cl, Davis MF, Himmel ME, Adney WS, Johnson DK: Cellulase digestibility of pretreated biomass is limited by cellulose accessibility. Biotechnol Bioengineer 2007, 98:112-122.

35. Kumar R, Wyman CE: Effect of xylanase supplementation of cellulase on digestion of corn stover solids prepared by leading pretreatment technologies. Bioresour Technol 2009, 100:4203-4213.

36. Kerley MS, Garleb KA, Fahey GC Jr, Berger LL, Moore KJ, Phillips GN, Gould JM: Effects of alkaline hydrogen peroxide treatment of cotton and wheat straw on cellulose crystallinity and on composition and site and extent of disappearance of wheat straw cell wall phenolics and monosaccharides by sheep. J Anim Sci 1988, 66:3235-3244

37. Gruno $M$, Väljamäe $P$, Pettersson $G$, Johansson G: Inhibition of the Trichoderma reesei cellulases by cellobiose is strongly dependent on the nature of the substrate. Biotechnol Bioengineer 2004, 86:503-511.

38. Edwards JK, Solsona B, N EN, Carley AF, Herzing AA, Kiely CJ, Hutchings GJ: Switching off hydrogen peroxide hydrogenation in the direct synthesis process. Science 2009, 323:1037-1041.

39. Yang B, Willies DM, Wyman CE: Changes in the enzymatic hydrolysis rate of Avicel cellulose with conversion. Biotechnol Bioengineer 2006, 94:1122-1128.

40. Quereshi N, Saha BC, Hector RE, Cotta MA: Removal of fermentation inhibitors from alkaline peroxide pretreated and enzymatically hydrolyzed wheat straw: production of butanol from hydrolysate using Clostridium beijerinckii in batch reactors. Biomass Bioenergy 2008, 32:1353-1358.

41. Dhar R, Sägesser R, Weikert C, Yuan J, Wagner A: Adaptation of Saccharomyces cerevisiae to saline stress through laboratory evolution. $J$ Evol Biol 2011, 24:1135-1153.

42. Samani P, Bell G: Adaptation of experimental yeast populations to stressful conditions in relation to population size. J Evol Biol 2010, 23:791-796.

43. Zheng DQ, Wu XC, Tao XL, Wang PM, Li P, Chi XQ, Li YD, Yan QF, Zhao YH: Screening and construction of Saccharomyces cerevisiae strains with improved multi-tolerance and bioethanol fermentation performance. Bioresour Technol 2011, 102:3020-3027.

doi:10.1186/1754-6834-4-16

Cite this article as: Banerjee et al: Alkaline peroxide pretreatment of corn stover: effects of biomass, peroxide, and enzyme loading and composition on yields of glucose and xylose. Biotechnology for Biofuels 2011 4:16.

\section{Submit your next manuscript to BioMed Central and take full advantage of:}

- Convenient online submission

- Thorough peer review

- No space constraints or color figure charges

- Immediate publication on acceptance

- Inclusion in PubMed, CAS, Scopus and Google Scholar

- Research which is freely available for redistribution

Submit your manuscript at www.biomedcentral.com/submit 